ORGANIZATIONAL LEARNING AS A SITUATED ROUTINE-BASED ACTIVITY IN INTERNATIONAL SETTINGS

\author{
By \\ Ayse Saka-Helmhout \\ School of Management, \\ University of Surrey, \\ Guildford, \\ Surrey GU2 7XH. \\ Tel: +44-1483- 689667 \\ Fax: +44-1483-689511 \\ a.saka-helmhout@surrey.ac.uk
}

Forthcoming in the Journal of World Business 2010, 45(1) 


\title{
ORGANIZATIONAL LEARNING AS A SITUATED ROUTINE-BASED ACTIVITY IN INTERNATIONAL SETTINGS
}

\begin{abstract}
A large body of research has extensively studied the mechanisms behind learning processes. However, there have been few studies of the learning process that explores influences of history, context, and social meaning in international settings. Rather, the focus within the international management field has been on knowledge transfer. This study adopts a situated routine-based view of organizational learning to highlight the influence of national institutional characteristics on the acquisition and enactment of new knowledge. It is based on in-depth case studies that systematically compare the ways in which Japanese parent company knowledge diffuses to subsidiaries in the UK automotive industry. It concludes that organizational learning within the context of multinational corporations is shaped by actors' enactment of new practices that are embedded in broader institutional contexts, where the links between knowledge transfer and the reinforcement of or change in routines are important in determining the level at which a subsidiary learns.
\end{abstract}

Descriptors: knowledge transfer, organizational learning, multinational corporations, routines, institutional context 


\section{INTRODUCTION}

The study of organizational learning has proliferated in the field of economics (e.g. Rosenberg, 1982), change management (e.g. Pettigrew, 1988), and strategic management research (e.g. Prahalad and Hamel, 1990). A large body of research has extensively studied the mechanisms behind learning processes (for a review, see Huber, 1991; Argote, 1999) However, there have been few studies of the learning process that explore the influences of history, context, and social meaning in international settings (see review by Easterby-Smith et al., 1999; exceptions include Hong et al., 2006). Most of the international management literature tends to equate organizational learning with knowledge transfer (e.g. Macharzina et al., 2001; Lane et al., 2001; Uhlenbruck et al., 2003) or the transfer of best practice that leads to firm survival and effective performance. Organizational learning as a routine-based, situated activity in international contexts has not received due attention. In the light of this development, this paper aims to highlight how national institutional characteristics influence the acquisition and enactment of new knowledge, i.e. the learning of alternative practices. Organizational learning in an international context is defined here as some combination of improving actions (Fiol and Lyles, 1985) and acquiring new knowledge (Hedberg, 1981), whether it is new products or processes, that is of strategic importance to the parent company.

Organizational learning is discussed in the following section as a routine-based activity that is embedded in particular institutional settings. This is followed by the introduction of the method and empirical setting. The findings of the exploratory study that examines the influence of national business systems on learning patterns at the British subsidiaries of two Japanese multinational corporations (MNCs hereafter) are presented in the fourth section. The final section presents the implications of adopting a 
routine-based understanding of learning situated in broader institutional contexts for research on the multinational firm.

\section{THEORETICAL BACKGROUND}

\section{Organizational Learning}

In line with the stream of research that perceives learning as taking place through participation in communities-of-practice (Lave and Wenger, 1991; Wenger, 1998) or based on practice (e.g. Gherardi, 2000), we are critical of the focus on learning as individual acquisition of knowledge that reflects abstract thinking. Organizational learning in international contexts is conceptualized here as consisting of two aspects: i) the acquisition of knowledge which relates to the cognitive aspects of learning, and ii) the impact that acquired knowledge has on routines within a particular context, i.e. the reinforcement of or change in routines. In this section, these two constructs that serve as the unit of analysis are presented. The distinction between acquisition and enactment of knowledge aligns with Brown and Duguid's (1991), and Lave and Wenger's (1991) understanding of learning through practice, where ‘knowledge acquisition' represents abstract knowledge or the 'what' of learning, and 'the reinforcement of or change in routines' reflects actual practice or the 'how' of learning.

\section{Knowledge acquisition}

There is broad consensus within the international management field on Vernon's (1979) assertion that multiple flows of intra-organizational knowledge between international units are an important source of competitive advantage in global industries. It is widely acknowledged that cross-border creation, accumulation and sharing of knowledge enable MNCs to create synergies (e.g. Bartlett and Ghoshal, 1989; Gupta and Govindarajan, 1991). The systemic advantages of combining geographically 
dispersed external and internal knowledge sources call for a need to establish strong informal ties between subsidiaries (Ghoshal and Nohria, 1989). The ability to capitalize on the resources of individual national subsidiaries and to leverage them to create innovations for exploitation on a worldwide basis is accepted as becoming increasingly important (e.g. Doz et al., 2003). This points to the importance of knowledge transfer that presents opportunities for learning at both the subsidiary and the corporate level (Kotabe et al., 2007). However, this celebrated notion of knowledge transfer has been widely used as a proxy for organizational learning (e.g. Macharzina et al., 2001; Lane et al., 2001; Uhlenbruck et al., 2003). We argue here that, for learning to be claimed, knowledge upon its transfer has to be manifested in changed behaviour.

\section{Reinforcement of or change in routines}

In line with Levitt and March (1988), we ascribe to the definition of learning as embedding or encoding of acquired knowledge into routines that guide behaviour. Learning is perceived here as taking place when acquired knowledge either reinforces or changes routines (adapted from Fiol and Lyles, 1985).

The definition of learning adopted here encompasses more than just a change in states of knowledge and the associated action outcomes. It incorporates the role of agency and the social context in which learning is shaped. Learning is not represented by the adoption of practices alone but is realized upon the routinization of practices or change in pre-existing routines that indicate a particular level of learning. This involves agency or the ability to remember the past, imagine the future, and respond to present circumstances (Emirbayer and Mische, 1998). Discerning the particular intentions of actors helps discern between why routines may change over time or persist (ibid.).

The reinforcement of routine behaviour by acquired knowledge is conceptualized as lower-level learning. We associate lower-level learning with 'those activities which 
add to the knowledge base or firm-specific competences or routines of the firm without altering the nature of their activities' (Dodgson, 1993: 383). This type of learning is directed at simple maintenance or elaboration of existing routines for efficiency and effectiveness (Hendry et al., 1995). By contrast, higher-level learning refers to the development of new routines, which can be seen as a discontinuous process, shifting from the state of rules to state of no rules. In considering organizational history and path-dependent behaviour in routine development (Cyert and March, 1963), it can be argued that breakaway from routines constitutes higher-level learning. Lillrank (2003: 218) defines this as attaining better interpretative schemes: ‘[W]hereas routine is guided by procedures established in advance based on past experience, nonroutine work is adapted to information learned from the task as it unfolds'. This type of learning is directed at changing routines for new orientation to work (Hendry et al., 1995: 105).

Given the importance that we assign to the broader context in which learning unfolds, we outline below the institutional features that can shape learning patterns in organizations.

\section{Institutional Context of Learning}

The extent to which institutional differences between home and host countries influence knowledge transfer has been widely studied, in particular, by the historical neo-institutionalists (e.g. Geppert and Matten, 2006; Edwards et al., 2005; Ferner et al., 2005). It is this variant of institutional theory, which has informed various studies in comparative research, that informs our investigation (e.g. Hall and Soskice, 2001; Maurice and Sorge, 2000; Djelic, 1998). Its underlying rationale is that the peculiarities of a given national system of industrial production are associated with the variation in actors' ability to act legitimately across institutional settings. Historical institutionalism identifies the governance principles of each market economy or business system as the 
state, financial system, public training system, legal system, authority relations, and union strength (Whitley, 1996; 2000). Work practices, values, and coordination are commonly observed in these principles or systems. In other words, the dominant practices of firms in relation to work systems, reward systems, and employee governance combine to form distinctive configurations that are identified as 'national business systems' (Whitley, 1999) that play a pronounced role in shaping firm strategies (Whitley, 2007). We argue here that these distinctive configurations shape the way subsidiaries learn from MNCs differently. We examine below the differences in institutional settings between Japan and the UK to highlight the potential variation in the way subsidiaries learn from MNCs located in these contexts.

The highly coordinated national business system of Japan promotes collectivist values and tightly-knit networks that encourage low strike activity, absenteeism, and turnover (Whitley, 1999). Berggren and Nomura (1997) refer to this as 'alliance capitalism' where the elements of corporate governance, inter-industry competition, internal labour markets and permanent employment, and long-term supplier relationships are closely linked. Such relations are conducive to the development of firm-specific and highly tacit skills, which are further strengthened by in-house training, job rotation, and long-term commitments (Dore and Sako, 1997; Robinson, 2003). The norms governing trust and authority relations nourish close links between managers and employees and allow greater informal participation in decisions than in 'Western' plants (Lincoln and Kalleberg, 1990). Whitley (1999: 92) summarizes these as the paternalistic cultural legacy of Japan where there is relatively low task fragmentation, considerable worker discretion and involvement, considerable managerial control of work organization, variable separation of managers from workers, and high employer commitment to employment security for the core workforce. The economic downturn of 
the early 1990s has not fundamentally affected Japan's employment practices and the implications they have for participative management, team work and on-the-job training (Dirks et al., 2000; Clegg and Kono, 2002). It is argued that firms in highly-coordinated systems such as Japan find it challenging to transfer firm-specific advantages to foreign subsidiaries, for they are strongly embedded in social networks of close cooperation and high interdependency (Whitley, 2001).

By contrast, compartmentalized business systems, as that of the UK, encourage reliance on formal rules and procedures that facilitate delegation rather than on social networks and high interdependency (Whitley, 1999). They are characterized by ‘arm’s length’ relationships and a high degree of fragmentation and diversity (Lane, 1996). Industrial relations have been adversarial and employment security has been low (McMillan, 1996) with adversarial effect on investment in skills development by UK firms (Sako, 1992). In comparison to those in Japan, work systems are considered to be of lower tacitness in the UK (Inkpen and Dinur, 1998). Furthermore, as loose associations, firms are unable to share risks, hence undertake mainly short-term and low-risk investments in fixed capital, $\mathrm{R} \& \mathrm{D}$, and human resources development (Lane, 1998). Whitley (1999: 92) summarizes the cultural legacy of the UK as Taylorist where there is high task fragmentation, low worker discretion and involvement, high managerial control of work organization, high separation of managers from workers, and low employer commitment to employment security for core workers. As competences are not constrained by obligational ties to partners, they tend to be more mobile across nations. Foreign subsidiaries of such firms can develop distinctive capabilities quickly as they are not constrained by high levels of MNC control (Otterbeck, 1981). 


\section{METHOD}

The research was based on comparative case studies of learning in the UK subsidiaries of two Japanese MNCs. It aimed to investigate the processes whereby continuous improvement practices were enacted by actors within a given institutional context to generate a particular pattern of organizational learning.

The study was systematic in deriving common analytical dimensions and matching as many parameters at the host country level as possible for comparability of cases. The MNCs were chosen to represent the same country-of-origin, i.e. Japan. The rationale for the selection of Japan was twofold: i) it represented an institutional context where practices were highly localized, and ii) its automotive manufacturing sector represented an important industry from the standpoint of national competitiveness at the time of data collection. The number of Japanese investments was greater within the automotive sector than it was in other sectors such as semiconductors, chemical, pharmaceutical, textile, and food in the early 1990s (Invest UK, 1995). Given the UK’s active role in adopting the latest working to revolutionize its manufacturing skills and performance (Invest UK, 1999), there were abundant opportunities to observe incidents of learning in the UK operations of Japanese MNCs.

The selection of subsidiaries was based on their site location. Nissera UK was similar to Teniki UK (both pseudonyms) in terms of the form of ownership, company size, nature of acquired practices and sector, i.e. car component assembly. Polar cases, i.e. Japanese MNEs and their brownfield and greenfield subsidiaries in the UK, were chosen so that the learning process was 'transparently observable' (Eisenhardt, 1989). ${ }^{1}$ As the variation in national institutional settings was the same for the two cases, there was an attempt to seek diversity in terms of the mode-of-entry of Japanese MNCs. It was crucial for the type of analysis adopted in this study to select a 'positive' and a 
'negative' case. ${ }^{2}$ A brownfield case was selected with the expectation that lower-levels of learning or the reinforcement of existing routines would be observed owing to possible resistance by the workforce to new methods of organizing. Whereas, being new from the outset, a greenfield site could be expected to be the ideal home for new practices based on unitarism (Beaumont, 1990; Leopold and Hallier, 1999), leading to higher-level learning or change in routines. The choice of the home and host contexts was based on the assumption that when practices are highly localized and acquired through engagement in specific action contexts, they can prove 'sticky' to diffuse to foreign firms (Szulanski, 1996), and need to be reinterpreted to be adopted in a new context. This is especially the case in Japan, where business activities are generally carried out in accordance with highly implicit rules and social norms (e.g. Whitley, 1999).

The research aimed to capture artefacts as "they have been particularly prominent as a means of collecting data about routines” (Pentland and Feldman, 2005, p. 796). It examined the enactment of continuous improvement practices, i.e. teambased structure, and team culture, which are identified in the Japanization literature as significant aspects of work systems associated with Japanese MNCs (e.g. Lincoln and Kalleberg, 1990; Dedoussis, 1995). These artefacts, or the type of knowledge transferred, were of systemic nature, i.e. there was the introduction of new procedures and systems with behavioural consequences (Child, 1994).

Case studies (see Table I), employing 40 semi-structured interviews conducted between 1998 and 2000, were carried out with Japanese advisors, directors, UK team leaders, operators and managers across areas of personnel and training, sales and marketing, product engineering, design and quality, finance, and purchasing in the UK sites. Interview data were complemented by a week-long participant observation in the 
UK subsidiary firms, which provided the means to capture actors' enactment of systemic artefacts. Information was also gathered through factory tours and interviews conducted with Japanese managers in international operations, production, general affairs, quality assurance, corporate finance, engineering, and corporate planning and control functions in Japan. The interview questions addressed the nature of the relationship and the division of responsibility between the Japanese parent and the subsidiary, the means by which continuous improvement practices were diffused, the factors that facilitated and inhibited the diffusion process, perceived cultural and managerial differences, and learning opportunities available to both the parent and the subsidiary.

Table I about here

The reliability of the findings was enhanced by making explicit the procedures that were followed for data collection. These procedures included matters of interview protocol, tape recordings of interviews and feedback on transcriptions from the participants. Within case companies, interview data from a particular work group were checked against responses from another group to validate findings. Similarly, subsidiary and headquarter members’ accounts were cross-checked against each other.

Learning was measured as 'higher-level' where the subsidiary displayed new patterns of thinking about business objectives, and accepted alternative practices from headquarters and changed their routines. 'Lower-level' learning was measured by an actor's orientation to iterate practices or to rely on past behaviour.

Initially, detailed case studies were conducted that captured contextualities in learning. This first step determines the main conditions to a given outcome within each 
particular case. This was followed by a comparison across cases conducted systematically using Mill's (1974) rigorous method to allow for theoretical generalization. This second step determines necessary and unnecessary conditions but also a possible multiplicity of paths towards the same outcome. Mill’s (1974) 'method of difference' was adopted for comparing cases with different learning patterns. In other words, an instance of a phenomenon's occurrence was compared with an instance of its non-occurrence to identify 'bundles of conditions' that explained for the variation in outcome. Open coding and axial coding were used to identify categories and related sub-categories respectively for a given level of learning (Strauss and Corbin, 1998). For instance, the responses to the question on barriers to/facilitators of transfer of practices focused on training. As other respondents acknowledged this, theoretical saturation was reached and 'training' was included as a category in the analysis. Sub-categories were identified on the basis of the categories' properties and dimensions such as the 'nature of and emphasis on training'. To verify the explanatory power of the codes, axial coding was carried out to relate sub-categories or conditions to the learning outcome (see the appendix for an illustrative list of codes and their definitions as well as the statements denoting how these are related).

Mill's technique is a method of elimination based on the 'successive exclusion of the various circumstance which are found to accompany a phenomenon in a given instance, in order to ascertain what are those among them which can be absent consistently with the existence of the phenomenon' (ibid., p. 392). Its advantage is that it enables one to capture both the general patterns of causalities or regularities across countries and contextual singularities. The diversity in learning outcomes ensured that Mill's method could be applied to the cases where cross-case patterns could be viewed through the lens of 'configurations' (combination of conditions) rather than 
'relationships between variables' (see Ragin, 1987). The method is well-suited for comparative studies of business, including historical institutionalism, with a long tradition in sociology and political science since it explicitly conceptualizes cases as combinations of attributes. In other words, it does not disaggregate cases into independent, analytically separate aspects, but, instead, treats configurations as different types of cases (Jackson and Deeg, 2008). Historical institutionalism views institutions as interdependent configurations rather than in isolation (Aoki, 1994).

One of the sites, Teniki UK, was owned by a British firm before being acquired by a Japanese car component manufacturer, Teniki, in 1996. The medium-sized company was run by a group of directors with limited sales and product types, and weak control prior to the acquisition. Following the acquisition, senior management was replaced with a more market-oriented, quality-conscious team. This team was advised by six Japanese expatriates in technical and development, operations, and sales and marketing areas. The 'people’ side of management was left to local managers.

The second case company, Nissera UK, was founded as a greenfield site in 1988 as part of a strategy to serve major Japanese customers in Europe. It employed 300 people in 1999, and had 60 per cent Japanese employees in the initial years of its foundation. As greater number of British managers were hired to fill in production roles, this percentage dropped to 6 per cent with a total of 12 Japanese managers in senior director, engineering and financial positions, serving liaison roles between the subsidiary and the parent company.

\section{FINDINGS}

The case studies demonstrate that there is heterogeneous learning across the two companies. Conscious efforts to institutionalize meanings and values produce 
considerable differences in learning owing to the variation in organizational initiatives embedded in different national business systems. In spite of the similarity in practices acquired by both subsidiaries as well as the same institutional gap between the home (Japan) and host (UK) countries, learning at Nissera UK was of higher level than that at Teniki UK.

\section{The Introduction of a Team Structure}

There was a shift in authority relations at both Teniki UK (in 1999) and Nissera UK (in 1997) towards a flatter organizational structure on the shop floor. Relations between superintendents, supervisors and hourly-paid workers were changed to those between team leaders, team coaches and hourly-paid workers arranged in a production cell layout to reduce costs and supervisory autonomy. However, the fluid job descriptions evident in the Japanese parent company were not widely observed in either of the UK subsidiaries. Operators perceived team leaders as members of the managerial team with clearly defined responsibilities: "team leaders do not do the work. As long as they make sure the system is in, what comes out is efficiency, cost and quality" (production manager at Nissera UK). By the same token, "we had less number of supervisors, hence it was a cost-saving measure in that way. We had a lot who did not understand the difference between a team coach and a supervisor' (personnel and training assistant at Teniki UK). Although operators at both subsidiaries were cynical about the structural change, observations showed that those at Nissera UK achieved greater success in changing their routines to work in a team-based structure than the operators at Teniki UK. The high concentration of Japanese expatriates during the early years after the company's establishment aided in enhancing local operators' skills. Whereas, at Teniki UK, the segregation between management and workers remained 
strong even after the company's acquisition in 1996. As is further exemplified in the next section, the low skills level of the operators and indirect involvement of Japanese expatriates in shop-floor activities led to difficulties in instilling high levels of commitment among Teniki UK operators, and encouraged reinforcement of routines through reliance on the past.

\section{The Instilling of Team Culture}

Teniki UK and Nissera UK had difficulty in securing the commitment of all members to parent company's continuous improvement activities such as quality circles, discipline in the workplace and the '5C' housekeeping principles of classifying, clarifying, cleanliness, clean-up, and custom.

Operators at Teniki UK did not subscribe to the Japanese belief that good housekeeping improved work habits and quality of facilities. For example, the older workers at the company worked according to their own rules, and enjoyed the freedom created by a weak control mechanism on the shop floor: "People do not read the quality audits. They just put a check. Somebody at the end of the day should look at the sheets” (senior operator in air element at Teniki UK). They also manipulated scrap-rate figures under production pressures: "Quality Assurance is called over when there is a supplierrelated problem. If there is pressure to get the order out, then they will pass the item that I would normally scrap” (assembler at Teniki UK). Furthermore, they manhandled machines when they did not work properly, ate and drank in their cells, and failed to fill in production timesheets on an hourly basis: "I do it at the end of the day and take an average. It looks better that way” (assembler at Teniki UK). Small-group activity could not be successfully implemented at Teniki UK, because the training and development plan had not yet instilled a continuous improvement culture. 
I believe people understand that they need to cut costs in the business. However, the adoption of the approaches and the ownership of correcting the problems, they do not do. That again is partly through training and the pressure on the business, not being able to release them to train because the first thing we need to do is to keep our customer happy. (operations manager at Teniki UK)

The previous owners at Teniki UK had focused on imparting operators with skills that were related to an operator's immediate task rather than the overall production process. Although job training under Japanese management was typically provided internally and involved consultation with staff, the UK workforce did not have the skill levels to change routines for a sustainable continuous improvement in the plant (operations manager at Teniki UK): “Teniki UK is located in an area popular for farming and armed forces. It is not an industrial location, so the education level is not that high. 60 per cent of the people have not more than three GCSEs [Graduate Certificates for Secondary Education]” (personnel and training manager at Teniki UK).

Although operators at Nissera UK could break away from old routines and habitualize a team culture to a greater extent than those at Teniki UK, the normative meaning attached to new practices differed from that underlying practices at the Japanese parent company. Initiatives mediated by local management were perceived as less straightforward in their effects: "ideas are good but the outlook, seeing it through is crap” (operator in cluster assembly at Nissera UK).

We were forced to go on this course [on quality circles]. They called it 'family circle'. It is a big joke. Everything is a joke. It could be better if they were straighter with us. As far as we are concerned, they have 
deceived us. They will start with something and if it does not suit them, they will change it. (operator in cluster assembly at Nissera UK)

There was low sense of responsibility for quality control processes. The author's own shop-floor work experience pointed to inconsistency in the application of quality standards whereby out-of-control measures were recorded by operators as falling within tolerance levels. Similar operator enactments were observed in component testing where tests on fuel and temperature indicators that normally took seven minutes to complete were ended after two or three minutes to meet production goals.

The introduction of a team structure and team culture needs to be considered in conjunction with the exercise of control through direct supervision and the use of expatriates. There was high level of control at both Teniki UK and Nissera UK in technical and strategic affairs. However, the level of involvement by Japanese expatriates in day-to-day running of the business was not as high at Teniki UK as it was at Nissera UK. Rather, there was considerable financial pressure on Teniki UK from the parent company for rapid profitability. The emphasis on clear-cut quantitative objectives at both strategic and operational levels had repercussions for the development of skills at Teniki UK.

Teniki [Japanese parent company] have pressure on them to put pressure on ourselves to make the returns faster than normal. In that case, we have had to have very stringent sort of budgetary control and cutting of budgets which would affect the long-term, that is training budgets are not as good as they should be in my belief. (operations manager at Teniki UK)

The way the company development has been financed has restricted [the adoption of continuous improvement practices]. Japanese normally take a 
very long-term view in any investment. They are always for the future. For some reason, the way this business has been financed is through short-term loans instead of a large share capital by the parent company. And the request has been that we make a very quick return on the investment whereas normally you would have maybe a few years' grace. (operations manager at Teniki UK)

Although the parent company of Nissera UK was heavily involved in technology and investment related decisions, it did not exercise stringent budgetary control over its UK operation in the first three years following its establishment. Rather, it exerted control through direct supervision and the use of expatriates.

Sometimes we do not chase profit. Otherwise we would be money traders. We invest. Our profit is generated from the products we manufacture. We sometimes try to forget about profitability. For the first three years, we do not expect a profit. We expect a profit in the fourth, fifth year. (manager in the corporate planning and control department at Nissera)

The learning patterns at the two companies are summarized in Table II.

Table II about here

\section{DISCUSSION AND CONCLUSIONS}

Although the subsidiaries have acquired similar continuous improvement practices and are exposed to the same institutional gap between Japan and the UK, there is divergence in the level at which they have learnt these practices. This hinges upon the role of agency in shaping action at the two companies. The acquisition of continuous 
improvement practices per se does not reveal how knowledge is connected to changes in behaviour. The specificity of organizational learning lies in contextualizing knowledge through its link to enactment. The impact that acquired practices have on learning patterns at subsidiaries is influenced by the parent company's orientation to building competence, i.e. nature of training and control. For instance, the effects of hands-on, extensive training; and direct forms of control on learning and a strong skills base in the region in which to do this are conspicuous in Nissera's efforts to transfer continuous improvement practices of team structure and team culture that encourage change in routines at the UK site. This is in line with Inkpen and Dinur's (1998) finding that attempts to integrate subsidiaries strategically, such as personnel transfers, provide the means of interacting and exchanging knowledge that makes it easier to put knowledge into practice.

The Japanese expatriates' direct involvement in developing capabilities at Nissera UK imparted the local workforce with a sense of the whole integrated production system that encouraged the adoption of new patterns of thinking about production objectives. The training of operators by the Japanese resembled the masterapprentice relationship in which skills were acquired “not through language but through observation, imitation, and practice” (Nonaka and Takeuchi, 1995: 63). This contrasts with 'Western' firm's emphasis on standardized knowledge that can be easily transferred. "Western firms lose much of their potential for knowledge creation by overemphasizing explicit knowledge and the development of complex managerial hierarchies, systems and standardization” (Inkpen and Dinur, 1998: 457). The emphasis on international transfer of managers and hands-on training (i.e. informal or indirect personal control, Harzing, 1999) served to acculturate the UK workforce (e.g. Selmer and De Leon, 1996). In comparison, Teniki had few headquarters personnel serving its 
UK subsidiary, and provided limited training in a hands-off manner. This reflects the characteristic of the broader national institutional system of the UK which is seen as deficient in skills training (Lane, 1996), and as encouraging task fragmentation and the separation of managers from workers (Whitley, 1999). Teniki chose to standardize and formalize rules, procedures and policies to co-ordinate and control activities. Given the limited coaching role of expatriate managers, change in routines to meet parent company mandates could not be observed at Teniki UK. For example, older workers failed to fill in production time sheets on an hourly basis, preferring to take an average of the production figures at the end of the day because "it looks better that way" (senior operator in air element at Teniki UK).

The greenfield set-up of Nissera UK also had a role to play in its higher-level learning (e.g. Leopold and Hallier, 1999; Ferner and Varul, 2000). Nissera UK made applicants aware that they were seeking committed employees, in return for good working conditions, above average pay and training opportunities. Operators were engaged on the understanding that they would work in teams, share jobs, and multiskill. The workforce had fewer preconceptions of manufacturing practices along the lines of union activity and craftsmanship than those at Teniki UK: "We need the trade union down here to improve the work environment" (a senior operator in the Air Element section at Teniki UK). Consequently, Nissera UK workforce responded to continuous improvement practices with an orientation to revising production systems that was directed at the future needs of the organization. The role of actors in shaping acquired knowledge was evident in the meanings that were attached to new practices (Hayes and Allinson, 1998). Alternative methods could not be habitualized in instances where the original meaning of Japanese practices, which are embedded in a highlycoordinated national business system, could not be shared by the UK adopters operating 
in a compartmentalized business system. For example, the instilling of team culture that had behavioural consequences was more challenging than that of a change in shop-floor structure. As Child (1994) argues, techniques that do not require a major change in behaviour create common meanings and identities more easily leading, in the context of this study, to higher-level learning. This confirms findings from previous research that culture-bound practices tend to generate problems of mutual adjustment (Liu and Vince, 1999). Actors' response to strongly embedded practices tends to be one of iteration with heavy reliance on past behaviour (Howard-Grenville, 2005).

Unlike what has commonly been in the limelight in cross-national learning research (e.g. Lane et al., 2001), this study shows that organizational learning in international settings is more than a process of transferring best practices. There is not a mimetic type of learning that leads to uniform outcomes across foreign operations. To conceptualize learning as knowledge transfer severely limits the role of human agency. Whereas, learning in 'agentic terms' highlights actors' recognition, location, and implementation of knowledge in their ongoing transactions that are situated in broader institutional settings. By adopting a routine-based understanding of learning, we reconcile the two aspects of learning, i.e. knowledge acquisition and encoding into routines, for a more refined understanding of the concept within the MNC context.

The findings have implications for parent company and subsidiary managers. They point to the importance of emphasizing both tacit and explicit practices in continuous improvement to create an environment that is a nexus for learning and creativity. They further demonstrate that a long-term perspective and hands-on approach to management can build the employee commitment necessary in the implementation of alternative methods of operating. Given that "workplace-centred, co-operative human resource strategies are at the heart of Japan's industrial success and several features of 
this approach are distinctive” (Fruin, 1997: 212), it is crucial for managers to recognize the institutional attributes of these practices in recreating firm-specific competences across national boundaries.

Contextualist and processual accounts of learning that recognize the link between knowledge and action in the international arena deem more empirical research. It is not sufficient to argue that learning that is disembodied from practice is fostered by diversity in experience and the differences between acquired and acquiring firms (e.g. Barkema and Vermeulen, 1998). The highly interactive and contentious nature of learning requires the need to carry out more phenomenological studies that highlight the link between knowledge acquisition and enactment in routines and a holistic analysis of contexts whereby institutions as configurations are compared to understand diversity. This would address some of the failings, as outlined by Redding (2005), in international business scholarship, in particular the privileging of either context-free rational agency and determinacy, or the variable-based approaches to understanding contexts (Jackson and Deeg, 2008) over subtle and less explored influences of history, context and social meaning systems.

\section{ENDNOTE}

1. The larger project from which this study was drawn investigated three cases. Although the third case was located in a traditional manufacturing base (hence was similar in its regional context to the brownfield site), its emphasis on hands-on skills development and the direct involvement of technical collaborators encouraged higher rather than lower levels of learning. 
2. Positive cases are those where outcomes across them are common and there are similarities in the combination of conditions that account for that outcome. Whereas, negative cases are those in which the phenomenon of interest is absent (Ragin, 1987).

\section{REFERENCES}

Aoki, M. (1994). 'The Japanese firm as a system of attributes', in M. Aoki and R. Dore (eds.), The Japanese Firm: Sources of Competitive Strength, pp. 11-40. Oxford: Oxford University Press.

Argote, L. (1999). Organizational Learning: Creating, Retaining and Transferring Knowledge. Boston: Kluwer Academic Publishers.

Barkema, H. and Vermeulen, F. (1998). 'International expansion through start-up or acquisition: A learning perspective’. Academy of Management Journal, 41: 7-26.

Bartlett, C. and Ghoshal, S. (1989). Managing Across Borders: The Transnational Solution. Boston, Massachusetts: Harvard Business School Press.

Beaumont, P. (1990). Change in Industrial Relations. London: Routledge.

Berggren, C. and Nomura, M. (1997). The Resilience of Corporate Japan: Competitive Strategies and Personnel Practices. London: Paul Chapman.

Brown, J. S. and Duguid, P. (1991). 'Organizational learning and communities-ofpractice: Toward a unified view of working, learning, and innovating'. Organization Science, 2: 40-57.

Child, J. (1994). Management in China during the Age of Reform. Cambridge: Cambridge University Press.

Clegg, S. and Kono, T. (2002). 'Trends in Japanese management: An overview of embedded continuities and disembedded discontinuities', Asia Pacific Journal of Management, 19: 269-85.

Cyert, R. M. and March, J. G. (1963). A Behavioural Theory of the Firm. Englewood Cliffs, New Jersey: Prentice-Hall.

Dedoussis, V. (1995). 'Simply a question of cultural barriers? The search for new perspectives in the transfer of Japanese management practices', Journal of Management Studies, 32: 731-45.

Dirks, D., Hemmert, M., Legewie, J., Meyer-Ohle, H. And Waldenberger, F. (2000). 'The Japanese employment system in transition', International Business Review, 9: 52553. 
Djelic, M. L. (1998). Exporting the American Model: The Post-war Transformation of European Business. Oxford: Oxford University Press.

Dodgson, M. (1993). 'Organizational learning: A review of some literatures'. Organization Studies, 14: 375-94.

Dore, R. and Sako, M. (1997). How the Japanese Learn to Work. London: Routledge.

Doz, Y., Santos, J. and Williamson, P. (2003). From Global to Metanational: How Companies Win in the Knowledge Economy. Boston: Harvard Business School Press.

Easterby-Smith, M., Burgoyne, J. and L. Araujo (1999). Organizational Learning and the Learning Organization: Developments in Theory and Practice. London: Sage Publications.

Edwards, T., Almond, P., Clark, I., Colling, T. and Ferner, A. (2005). 'Reverse diffusion in US multinationals: Barriers from the American Business System', Journal of Management Studies, 42: 1261-86.

Eisenhardt, K. M. (1989). Building theories from case study research'.Academy of Management Review, 14: 532-50.

Emirbayer, M. and Mische, A. (1998). 'What is agency?'. American Journal of Sociology, 103: 962-1023.

Ferner, A. and Varul, M. (2000). "'Vanguard subsidiaries" and the diffusion of new practices: A case study of German multinationals'. British Journal of Industrial Relations, 38: 115-40.

Ferner, A., Almond, P. and Colling, T. (2005). 'Institutional theory and the crossnational transfer of employment policy: The case of "workforce diversity' in US multinationals', Journal of International Business Studies, 36: 304-321.

Fiol, C. M. and Lyles, M. A. (1985). 'Organizational learning’. Academy of Management Review, 10: 803-13.

Fruin, W. M. (1997). Knowledge Works: Managing Intellectual Capital at Toshiba. Oxford: Oxford University Press.

Geppert, M., and Matten, D. (2006). 'Institutional influences on manufacturing organization in multinational corporations: The 'cherrypicking' approach', Organization Studies, 27: 491-515.

Gherardi, S. (2000). 'Practice-based Theorizing on Learning and Knowing in Organizations: Introduction to the Special Issue on Knowing in Practice', Organization 7: 211-23.

Ghoshal, S. and Nohria, N. (1989). 'Internal differentiation within multinational corporations’. Strategic Management Journal, 10: 323-37. 
Gupta, A. K. and Govindarajan, V. (1991). 'Knowledge flows and the structure of control within multinational corporations'. Academy of Management Review, 16: 76892.

Hall, P. A. and D. Soskice (2001). Varieties of Capitalism: The Institutional Foundations of Comparative Advantage. Oxford: Oxford University Press.

Harzing, A.-W. K. (1999). Managing the Multinationals: An International Study of Control Mechanisms. Cheltenham: Edward Elgar.

Hayes, J. and Allinson, C. W. (1998). 'Cognitive style and the theory and practice of individual and collective learning in organizations’. Human Relations, 51: 847-71.

Hedberg, B. (1981). 'How organizations learn and unlearn?', in Nystrom, P. C. and Starbuck, W. H. (Eds), Handbook of organizational design., pp. 8-27. London: Oxford University Press.

Hedlund, G. and Nonaka, I. (1993). 'Models of knowledge management in the West and Japan' in P. Lorange, B. Chakravarthy, J. Roos and A. Van de Ven (eds.), Implementing Strategic Processes: Change, Learning, and Cooperation, pp. 117-144. Oxford: Basil Blackwell.

Hendry, C., Arthur, M. B. and Jones, A. M. (1995). Strategy Through People: Adaptation and Learning in the Small-Medium Enterprise. London: Routledge.

Hong, J. F. L., Easterby-Smith, M. and Snell, R. S. (2006). 'Transferring organizational learning systems to Japanese subsidiaries in China. Journal of Management Studies, 43: 1027-58.

Hong, J. F. L., M. Easterby-Smith and Snell, R. S. (2006). 'Transferring Organizational Learning Systems to Japanese Subsidiaries in China', Journal of Management Studies, 43: 1027-1058.

Howard-Grenville, J. A. (2005). 'The persistence of flexible organizational routines: The Role of agency and organizational context'. Organization Science, 16: 618-36.

Huber, G. P. (1991). 'Organizational learning: The contributing processes and the literatures’. Organization Science, 2: 88-115.

Inkpen, A. C. and A. Dinur (1998). 'Knowledge management processes and international joint ventures’, Organization Science, 9: 452-68.

Invest UK (1995). Japanese Manufacturing Companies in the UK, 3 October. London: Department of Trade and Industry.

Invest UK (1999). Invest in Britain. London: Department of Trade and Industry.

Jackson, G. and R. Deeg (2008). 'Comparing capitalisms: Understanding institutional diversity and its implications for international business', Journal of International Business Studies, 39, pp. 540-561. 
Kotabe, M., Dunlap-Hinkler, D., Parente, R. and Mishra, H. A. (2007). 'Determinants of cross-national knowledge transfer and its effect on firm innovation', Journal of International Business Studies, 38: 259-82.

Lane, C. (1996). 'The social constitution of supplier relations in Britain and Germany: An institutionalist analysis', in: R. Whitley and P. H. Kristensen (Eds), The Changing European Firm: Limits to Convergence, pp. 271-304. Routledge, London.

Lane, C. (1998). 'European companies between globalization and localization: A comparison of internationalization strategies of British and German MNCs', Economy and Society, 27: 462-85.

Lane, P. J., Salk, J. E. and Lyles, M. A. (2001). 'Absorptive capacity, learning and performance in international joint ventures'. Strategic Journal of Management. 22: 1139-62.

Lave, J. and Wenger, E. (1991). Situated Learning: Legitimate Peripheral Participation. Cambridge: Cambridge University Press.

Leopold, J. W. and Hallier, J. (1999). 'Managing the employment relationship on Greenfield sites in Australia and New Zealand', International Journal of Human Resource Management, 10: 716-36.

Levitt, B. and March, J. G. (1988). 'Organizational learning'. Annual Review of Sociology, 14: 319-40.

Lillrank, P. (2003). 'The quality of standard, routine and nonroutine processes'. Organization Studies, 24: 215-33.

Lincoln, J. R. and Kalleberg, A. L. (1990). Culture, Control and Commitment: A Study of Work Organization and Work Attitudes in the United States and Japan. Cambridge: Cambridge University Press.

Liu, S. and Vince, R. (1999). 'The cultural context of learning in international joint ventures'. Journal of Management Development, 18: 666-75.

Macharzina, K., Oesterle, M.-J. and Brodel, D. (2001). 'Learning in multinationals', in Dierkes, M., Berthoin Antal, A., Child, J. and Nonaka, I. (Eds), Handbook of Organizational Learning and Knowledge, pp. 631-656. Oxford: Oxford University Press.

Maurice, M. and A. Sorge (2000). Embedding Organization. Amsterdam: John Benjamins.

McMillan, C. J. (1996). The Japanese Industrial System, $3^{\text {rd }}$ edition. Berlin: Walter de Gruyter. 
Mill, J. S. (1974). A System of Logic Ratiocinative and Inductive: Being a Connected View of the Principles of Evidence and the Methods of Scientific Investigation. Toronto: University of Toronto Press.

Nonaka, I. and Takeuchi, H. (1995). The Knowledge-Creating Company: How Japanese Companies Create the Dynamics of Innovation. New York: Oxford University Press.

Otterbeck, L. (1981). 'Concluding remarks and a review of subsidiary autonomy”, in L. Otterbeck (ed.), The Management of Headquarters Subsidiary Relationships in Multinational Corporations, 337-43. Aldershot: Gower.

Pentland, B. T. and Feldman, M. S. (2005). 'Organizational routines as a unit of analysis’ Industrial and Corporate Change, 14: 793-815.

Pettigrew, A. M. (1988). The Management of Strategic Change. Oxford: Basil Blackwell.

Prahalad, C. K. and Hamel, G. (1990). 'The core competence of the corporation'. Harvard Business Review, May-June: 79-91.

Ragin, C. C. (1987). The Comparative Method: Moving Beyond Qualitative and Quantitative Strategies. Berkeley, California: University of California Press.

Redding, G. (2005). 'The thick description and comparison of societal systems of capitalism'. Journal of International Business Studies, 36: 123-55.

Robinson, P. A. (2003). 'The embeddedness of Japanese HRM practices: The case of recruiting', Human Resource Management Review, 13: 439-66.

Rosenberg, N. (1982). Inside the Black Box: Technology and Economics. Cambridge, MA: Cambridge University Press.

Sako, M. (1992). Prices, Quality and Trust: Inter-firm Relations in Britain and Japan. Cambridge: Cambridge University Press.

Selmer, J. and De Leon, C. (1996). 'Parent cultural control through organizational acculturation: HCN employees learning new work values in foreign business subsidiaries’, Journal of Organizational Behavior, 17: 557-72.

Strauss, A. and Corbin, J. (1998). Basics of Qualitative Research: Techniques and Procedures for Developing Grounded Theory. Thousand Oaks: Sage Publications.

Uhlenbruck, K., Meyer, K. E. and Hitt , M. A. (2003). 'Organizational transformation in transition economies: Resource-based and Organizational learning perspectives'. Journal of Management Studies, 40: 257-82.

Vernon, R. (1979). 'The product cycle hypothesis in a new international environment'. Oxford Bulletin of Economics and Statistics, 41: 255-67.

Wenger, E. (1998). Communities of Practice. Cambridge: Cambridge University Press. 
Whitley, R. (1996). 'The social construction of economic actors: Institutions and Types of Firm in Europe and other Market Economies', in R. Whitley and P. H. Kristensen (eds), The Changing European Firm, pp. 39-66. London: Routledge.

Whitley, R. (1999). Divergent Capitalisms: The Social Structuring and Change of Business Systems. Oxford University Press, Oxford.

Whitley, R. (2000). 'The institutional structuring of innovation strategies: Business systems, firm types, and patterns of technical change in different market economies', Organization Studies, 21, pp. 855-886.

Whitley, R. (2001). 'How and why are international firms different? The consequences of cross-border managerial coordination for firm characteristics and behaviour', in G. Morgan, P. H. Kristensen, and R. Whitley (Eds), The Multinational Firm: Organizing across Institutional and National Divides, pp. 27-68. Oxford: Oxford University Press.

Whitley, R. (2007). Business Systems and Organizational Capabilities: The Institutional Structuring of Competitive Competences. Oxford: Oxford University Press. 
Table I. Case-study Firms

\begin{tabular}{|l|l|l|}
\hline & Teniki UK & Nissera UK \\
\hline Interviews in the UK & 18 & 14 \\
\hline Interviews in Japan & 2 & 6 \\
\hline Total interviews & 20 & 20 \\
\hline $\begin{array}{l}\text { Factory work experience in } \\
\text { the UK }\end{array}$ & For a week as an operator in car component assembly \\
\hline Factory tours in Japan & $\begin{array}{l}\text { Air cleaner, assembly, } \\
\text { injection and blow } \\
\text { moulding and press shops }\end{array}$ & $\begin{array}{l}\text { LCD production, case } \\
\text { assembly, R\&D centre }\end{array}$ \\
\hline
\end{tabular}


Table II. Patterns of Learning at Subsidiaries

\begin{tabular}{|c|c|c|}
\hline & Teniki UK & Nissera UK \\
\hline $\begin{array}{l}\text { National institutional } \\
\text { context }\end{array}$ & \multicolumn{2}{|c|}{ Variation in national business systems between the UK and Japan } \\
\hline Mode of entry of MNC & Acquisition & Greenfield site \\
\hline Skills base in the region & Low in manufacturing & High in manufacturing \\
\hline Size (in 1999) & Medium (170 employees) & Medium (300 employees) \\
\hline $\begin{array}{l}\text { Age (year of acquisition } \\
\text { or establishment-data } \\
\text { collection period) }\end{array}$ & 1996-1999 & $1988-1999$ \\
\hline Nature of work & Assembly of carbon canister, air intake systems & Assembly of vehicle instrument clusters \\
\hline Financial orientation & Short-term & Long-term \\
\hline $\begin{array}{l}\text { Number and roles of } \\
\text { Japanese expatriates }\end{array}$ & Four in advisory role & Twelve in mainly director role \\
\hline Workforce skills level & Low & Medium \\
\hline Nature of training & Hands-off, limited & Hands-on, extensive \\
\hline Exercise of control & $\begin{array}{l}\text { High, indirect through clear-cut quantitative } \\
\text { objectives }\end{array}$ & Direct supervision, expatriate control \\
\hline $\begin{array}{l}\text { Learning outcome } \\
\text { (Knowledge acquisition, } \\
\text { impact on routines) }\end{array}$ & $\begin{array}{l}\text { Lower-level } \\
\text { (Introduction of team structure and team } \\
\text { culture, reinforcement of routines) }\end{array}$ & $\begin{array}{l}\text { Higher-level } \\
\text { (Introduction of team structure and team culture, } \\
\text { change in routines) }\end{array}$ \\
\hline
\end{tabular}




\section{Appendix Illustrative List of Codes Associated with Learning}

\begin{tabular}{|c|c|c|c|}
\hline $\begin{array}{l}\text { Categories related } \\
\text { to the learning } \\
\text { outcome }\end{array}$ & Sub-categories & Teniki UK & Nissera UK \\
\hline \multirow[t]{2}{*}{$\begin{array}{l}\text { Training (i.e. means } \\
\text { of imparting workers } \\
\text { with the skills, know- } \\
\text { how to work with } \\
\text { continuous } \\
\text { improvement } \\
\text { practices }\end{array}$} & $\begin{array}{l}\text { Hands-on/Hands-off } \\
\text { nature of training }\end{array}$ & $\begin{array}{l}\text { The four Japanese advisors who are in a position to train } \\
\text { the operators are preoccupied with start-up projects, and } \\
\text { do not have the time to invest in training. }\end{array}$ & $\begin{array}{l}\text { The Japanese guy was very patient. He would tell you all you } \\
\text { needed to know. He explained things, like angle setting, } \\
\text { generally about the equipment. If there was a reject, it would go } \\
\text { to the line that produced the fault for rework. Japanese look for } \\
\text { the source of the problem. In the UK, you are just told what to } \\
\text { do. }\end{array}$ \\
\hline & $\begin{array}{l}\text { High/Low emphasis } \\
\text { on training }\end{array}$ & $\begin{array}{l}\text { I believe, people understand that they need to cut costs in } \\
\text { the business. However, the adoption and the ownership of } \\
\text { correcting the problems, they do not do. That again is } \\
\text { partly through training and the pressure on the business, } \\
\text { not being able to release them to train because the first } \\
\text { thing we need to do is keep our customer happy. }\end{array}$ & $\begin{array}{l}\text { Although, they had more strict rules, Japanese managers would } \\
\text { help you work. They would go to the source of the problem. } \\
\text { British managers make up titles and waste money. }\end{array}$ \\
\hline $\begin{array}{l}\text { Control (i.e. } \\
\text { monitoring of quality } \\
\text { standards) }\end{array}$ & $\begin{array}{l}\text { Direct/indirect } \\
\text { nature of control }\end{array}$ & $\begin{array}{l}\text { People do not read the quality audits. They just put a } \\
\text { check. Somebody, at the end of the day, should look at } \\
\text { the sheets. }\end{array}$ & $\begin{array}{l}\text { We were closely policed...the ex-managing director [Japanese] } \\
\text { used to say there is dirt on the floor. He also used to hit one’s } \\
\text { hand for not doing a good job. At the same time, we might have } \\
\text { run out of parts on a line. The second issue is more important for } \\
\text { the British. On a well-organised line the next biggest issue is } \\
\text { cleanliness. }\end{array}$ \\
\hline $\begin{array}{l}\text { Skills (i.e. } \\
\text { competences of } \\
\text { operators) }\end{array}$ & $\begin{array}{l}\text { High/Low level of } \\
\text { workforce skills }\end{array}$ & $\begin{array}{l}\text { The biggest thing, which we have not been successful in, } \\
\text { I suppose, is the Kaizen, small group activity work. We } \\
\text { all know the benefits of doing that...but unless the people } \\
\text { on the shop floor buy into them and understand them and } \\
\text { want to be part of them, it is not sustainable... Because } \\
\text { we have not cascaded the information down and have not } \\
\text { got the skills bottom up to top, we cannot achieve this } \\
\text { sustainable continuous improvement within the plant. }\end{array}$ & $\begin{array}{l}\text { We can easily select manufacturing staff. People can understand } \\
\text { our requirements...In the beginning, we asked for a lot of help } \\
\text { from the local staff, so we couldn’t provide job descriptions. } \\
\text { Brownfield site is more disadvantageous from that perspective. }\end{array}$ \\
\hline
\end{tabular}


